\title{
A Study Into Land Supply And Demand For Property Development In Colombo
}

\author{
Sepani Senaratne, Nisa Zainudeen
}

\begin{abstract}
This paper investigates the land market in Sri Lanka's main location in terms of economic activities - the Colombo Metropolitan Region (CMR). First, the paper addresses general issues relating to land market and factors affecting its demand and supply through a literature review. Subsequently, through a survey of land supply sources and secondary data, the study explores trends in land supply and land prices over a thirty year period, identifying specific reasons for the trends. In terms of land supply, the study's findings include the fact that a substantial amount of land in Colombo is not readily usable for development activities due to various reasons. The study also reveals a move from residential activities to commercial activities in the heart of Colombo and a considerable increase in land prices in the post Tsunami era. The suggestions include allowing this commercial sector to move towards the city centre to accommodate the high demand for commercial activities after the liberal economic policy introduced to the country in 1977.
\end{abstract}

\section{Introduction}

Land is indeed one of the vital resources of a country. It has also the characteristics of appreciating in value over time, thus, attracting investors on land (Perera, 1996). Moreover, Kiringoda (2002) has stated that, land is the most important, yet, the scarce resource in urban development. In the land market, the commodities traded are estates and interests in land, and one convention is to divide the market into its component parts on the basis of the estates and interests being traded.

According to Dowall (1993), land markets perform four important functions; namely,

1) They bring buyers and sellers together to facilitate transactions

2) They set prices for land;

3) They allocate land by setting prices so that the land market "clears", that is, the quantity of land offered for sale equals the quantity of land demanded; and

4) Land prices play an important role in ensuring that land is efficiently used.

Land market in Sri Lanka reveals a wide variety of features, which distinguish it from other markets. These features are predominantly economic in origin (Perera, 1996).

- Firstly, it is misleading to view 'the land market' as a single entity. It is more accurately considered as a number of individual markets which, though interrelated, are to a considerable extent independent of each other. This subdivision of the market can be based on a number of different criteria and when a transaction actually takes place, all of these criteria may be relevant.

- Secondly, the land market is featured with the extensive use of credit and the growth of financial institutions that are prepared to provide cash against the security of real property assets.

- Thirdly, the land market is characterized by the diversity of motives for participation, meaning not just the different motives that prompt one person to buy a factory and another a shop, but the motives urging different people toward wanting to buy the same plot of land for different reasons. Basically, the motivation can be divided into the desire for occupancy and that for investment. There is a distinction between the owner-occupier who receives the benefits in kind and the investor who is after cash return for, unlike the former, the latter sees land merely as a substitute for other kinds of investment.

- Finally, according to Perera (1996), a key factor that impairs the functioning of the land market is the lack of information, in particular, on the number of transactions, their pattern of distribution and the respective prices at which they are bought and sold. These give rise to imperfect or monopolistic competition with severe price differentiations. Often land regulations, including zoning controls and building statutory restrictions, can have a considerable influence on the property market(Hui, 2004). 
Thus, a study into land market to observe these special features and imperfect conditions is important in the context of property development.

\section{Research Methodology}

This research study aims at exploring the characteristics of land market, especially the supply trends of land in the Colombo Metropolitan Region (CMR), which is the most economically significant region in Sri Lanka. The several objective pointers needed to achieve the aim of this research study include:

- The identification of the various factors affecting land supply and demand;

- The identification of the various sources of land supply; and,

- The analysis into the land supply and demand trends.

At the outset, this study conducts a literature survey to explore the research issues relating to the factors affecting supply and demand of land in the CMR. Next, a primary survey is conducted using open-ended interviews to selected relevant persons, using document analysis as the main data collection technique. This open-ended field survey is confined to those significant public and recognized private sector organizations that are the source of supply of land in Sri Lanka. The interviews focused on questions such as factors affecting current land supply and demand in the region; the extent of land supplied by different agencies and the purpose for making these land parcels available. Further, land prices are obtained from secondary data, including conducting interviews with valuers and property developers.

The data received have been analyzed and the results formulated and plotted into graphs to extrapolate the trend of land supply and demand over time. For the scope of this analysis, seven land uses have been considered, namely: residential, industrial, transportation and circulation, commercial, cultural and recreational, institutional and vacant. Observed figures are plotted against each of the land uses as defined.

\section{Factors affecting Land supply and Demand: Lltarature Findings}

As Dowall (1993) argues, the demand for land is derived from various activities that require the use of land: housing, factories, retail shops, farms and government facilities. As Perera (1996) points out, urban land is competed by housing, industry, trade and commerce and other state services such as education, health and recreation, each attempting to outbid the other for the available space according to their respective strengths and weaknesses. The result invariably is a multitude of different types of land uses that typically characterise the modern city.

According to Perera (1996), the demand for urban land, like any other commodity, is determined by such factors as price, number of buyers, the income levels of buyers and other available options. The price of land is particularly determined by its location. The rate of population growth has a direct effect on the demand for land for housing. Further, the income levels of the population determine the effective demand. In terms of different options available, in high inflation environments, the demand for land as a hedge against inflation is substantial (Dowall, 1993).

Numerous studies have focused on the effects of the demand on land, however, very few have reflected the effects of land supply (Wiltshaw, 1985). Many later studies have focused particularly on land planning in various countries (for example, Barlow, 1993, for Europe; Evans, 1996, for Britain; Hui, 2004, for Hong Kong). In Sri Lanka, the key study done in this area is by Perera (1996). However, there has not been any significant study done to explore land supply and demand issues, especially in the period after 1996.

On the supply side, as Dowall (1993) emphasizes, the supply of land available for urban development is determined by topography, distribution of infrastructure, master plan and zoning policies, and the willingness of landowners to sell parcels. Steep slopes, wetlands and hazardous areas further limit the supply of land for urban development. Infrastructure networks also largely determine the supply of developable land (Perera, 1996). Government policies have the effect of limiting land supply especially when the land development policies are restrictive. Especially, land use zoning can affect the land supply and thereby land prices (Hui, 2004).

Perera (1996) reveals that the most significant problem facing property development is the relative scarcity of land. Land is essentially fixed in supply. However the competition for different potential uses can lead to the optimal use of land. While the supply of urban land in most developing countries can be substantially influenced by the above factors there can be specific factors related to a certain location.

For the City of Colombo, Perera (1996) has noted the following land supply paths:

a) Owners of small extents of land who offer to sell small parcels of primarily developed land mainly for residential or mixed residential or commercial purposes;

b) The conversion of low-lying marshy land to profitable use, augmenting the supply of land for commerce, trade and industry; 
(c) The sub-division of coconut and rubber plantations for housing in sub-urban areas;

(d) The filling of marginal paddy land for residential, commercial and industrial purposes by individuals without proper authorisation.

The next section analyses the research findings on the land market for property development in the Colombo region of Sri Lanka.

\section{Discussion on Survey Findings}

The survey findings are discussed in this section under three sections; namely, factors affecting land supply; land supply sources; and, land supply and demand patterns for property development projects in Colombo.

\section{Factors affecting land supply and demand in Colombo}

According to the Urban Development Authority (UDA) in Sri Lanka (1998a), the most important economic functions of Sri Lanka are located in Colombo Metropolitan Region (CMR). Investment on the CMR is economically viable and reasonable as it contributes to $44 \%$ of Gross Domestic Product (GDP) (as against the $36 \%$ of the annual public investment in the country in 1994) and it also provides sufficient land and space for future investment on economic development and urban expansion (UDA, 1998a: 1998b).

A main factor, which affects the land supply in the CMR, is the zoning plans with building regulations. The zoning plans and building regulations describe general requirements and conditions designed for the City. These are set to suite local conditions in terms of environmental characteristics, architectural design and urban form. It covers planning and designing policies, guidelines on land use, transport, environmental improvement, pedestrian and open space system, building height, intensity of development, conservation and redevelopment of areas and buildings. The changes to the urban structure and regional physical structure will lead to several consequences such as the acquisition of lands or properties for new rail tracks or roads; reservation of lands for future rail or road tracks; introduction of new street lines and building lines; zoning conservation areas such as areas prone to flooding, open spaces, urban forest, playground, urban agricultural and other retention areas; and, restriction of certain development in certain areas through zoning (concentrated development zone).

Other than the regulations and zoning plans, the land supply is affected in the CMR by drainage problems, social problems, and insufficient supply of water. Due to the effects of tsunami, some development projects have to be abandoned. Therefore, the demand of lands in the affected areas has gone down significantly. Coastal erosion and other forms of coastal degradation such as beach encroachment have an effect on the land supply.

Major issues of land use in the CMR are the incompatible uses of lands, the ad-hoc conversion and fragmentation of highland agricultural lands for urban activities, the increasing demands for reclamation of marshy lands and the filling of abandoned paddy fields for building construction. In order to address these issues, the followings actions have been proposed by interviewed participants, some of which have already been under active consideration by UDA.

- Identification of areas for concentrated high-density development (growth centres, industrial towns, satellite cities, cyber cities, etc.);

- Ildentification of green lung areas (marshes, paddy lands, flood detention cum recreational areas, etc.) that have to be preserved in their current form;

- Introduction of urban agriculture as a major urban function;

- Review of planning, zoning guidelines and development regulations for the Colombo Metropolitan Region.

On the demand side, interviews reveal several factors that can influence land prices. These include the rate of population growth, the legal and planning factors, the economic conditions and the social factors.

Even though the overall supply of land is fixed, the demand for land is increasing continuously due to the increasing rate of the population growth in the area. As a result, land price tends to increase. Human operations usually concentrate the demand for the land to certain locations such as at the heart of Colombo.

When there are legal constrains against the utilisation of lands, a low demand for land is observed. Legal restrictions have a direct influence upon the human activities and the ownership of lands. On the other hand, devotion of certain territories through planning as eligible for certain human activities affects the demand for the land. People under the intention of performing and contributing to a particular occupation tend to gather into a certain location as they have more resources to perform. This is indeed an example of the effects of zoning distribution of land.

Economic factors and prevalent economic activities in a territory can influence the land prices in that territory. Further, international market conditions, sometimes, directly or indirectly influence the inland market 
condition. For instance, the local rubber land market is influenced by the changes in oil prices in the international market, as synthetic rubber is produced as a by-product of crude oil.

People are always attracted by the cultures most intimate for them and tend to occupy in certain locations. This may be due to the diversifications of people by factors such as ethnicity, language, religion, income level and educational backgrounds.

With the identification of above factors specific to land supply and demand in Colombo, the next section explores the land supply sources in Colombo region.

\section{Land supply sources in Colombo}

According to the field study, almost all developable plots of land in the City of Colombo have already been utilized for different purposes. There are, however, small individual parcels of land scattered throughout the City, which are being offered for housing and commercial use for relatively very high prices as revealed in Perera's (1996) study.

As explained in Section 3.0, a previous study (Perera, 1996) has found some formal and informal sources of land supply paths in the CMR. In addition to these, there are some key agencies who supply land for property development in Sri Lanka, mainly by the conversion of low-lying marshy lands. While Urban Development Authority (UDA) and the Board of Investment (BOI) mainly concentrate in the supply of land for industry, the National Housing Development Authority (NHDA) supplies land for housing of low and middle-income groups. There are private sector agencies who build houses mainly for the middle-income groups. Sri Lanka Land Reclamation and Development Corporation (SLLR\&DC) also supplies land for housing, commerce and industry.

The primary survey reveals that the majority of the available lands are under the ownership of UDA. The contribution of SLLR\&DC is also considerable. Most of the land under SLLR\&DC has yet to be reclaimed but there is the intention of immediate reclamation. Real Estate Exchange (pvt) Ltd (REEL), a private sector company, on the other hand, has the commendable intention of acquiring land for low income earning housing in Colombo mainly to resettle the occupants of those plots of land meant for development of high rise apartment complexes. Figure 1 depicts land suppliers in the Colombo region as found through the literature and field survey findings.

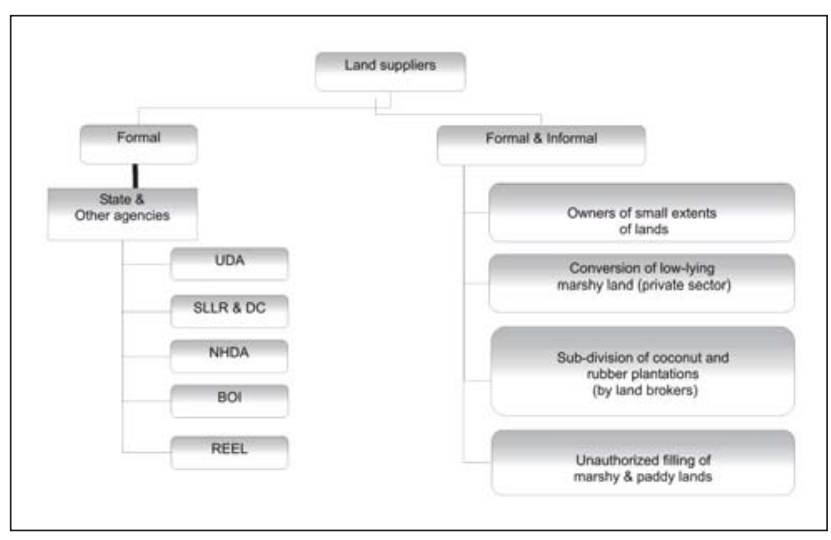

Figure 1: Land suppliers in Colombo

This study has been extended to identify lands, owned by key public land suppliers (UDA, SLLR\&DC and REEL) planning to make available plots of land for specific developments based on zoning categorization (see Figure 2). Accordingly, housing, commercial and industrial zones form, respectively, $8 \%, 3 \%$ and $18 \%$ of the whole sum of lands identified as available in the Colombo Metropolitan Region (CMR). Furthermore, 8\% of the total extent of lands available for development in CMR is identified as suitable for mixed-use developments.

On the other hand, there is a substantial amount of available land that cannot be readily used for development due to a variety of reasons. For example, $23 \%$ of the observed land in CMR can only be developed after the occupants can be relocated. The availability of another $13 \%$ of the observed land also depends on resettlement plans of occupants, A further $8 \%$ of the observed land cannot be immediately developed due to numerous legal and physical controversies. $6 \%$ of the remaining land available for immediate development is intended to be disposed off by the public tender process. A further $6 \%$ of this remaining land available for development has been devolved to certain companies for their own development activities under pre-established conditions, the exact usage of which have yet to be decided upon. A negligible extent of the land is idling at the moment with no development decision in mind. Figure 2 summarizes the above discussion.

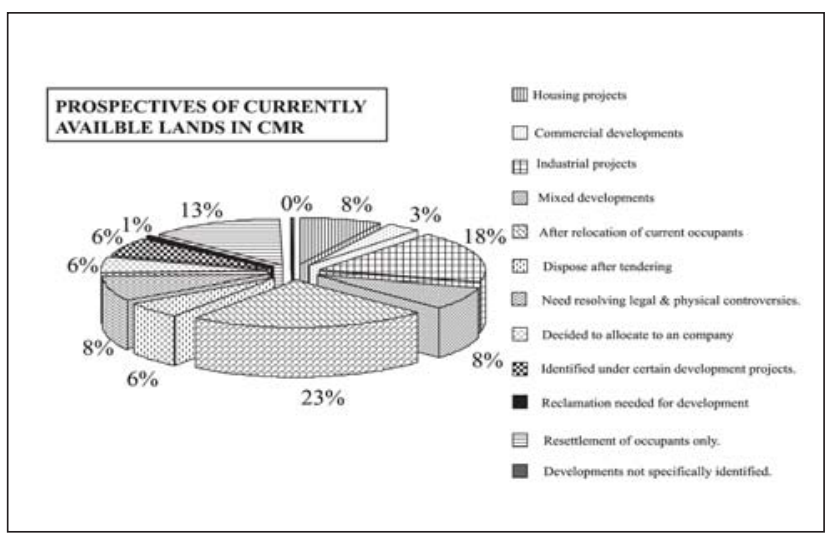

Figure 2: Division of currently available land for specific purposes 
The next two sections attempt to identify land supply and demand patterns over the years through the surveyed data.

\section{Land supply and demand patterns}

Based on the primary data collected through the interviews, figure 3 below shows the land supply pattern for different property sectors within the city of Colombo. Only 'net land supply' is considered in the figure. As land is a fixed resource, any development land to be supplied can only be done by a transformation of land currently being used uneconomically. Thus, 'net land supply' can be defined as the difference in the extent of land transformed from other sectors or from vacant aspect into the relevant sector under consideration and the land conveyed from that sector into other sectors or to the vacant aspect.

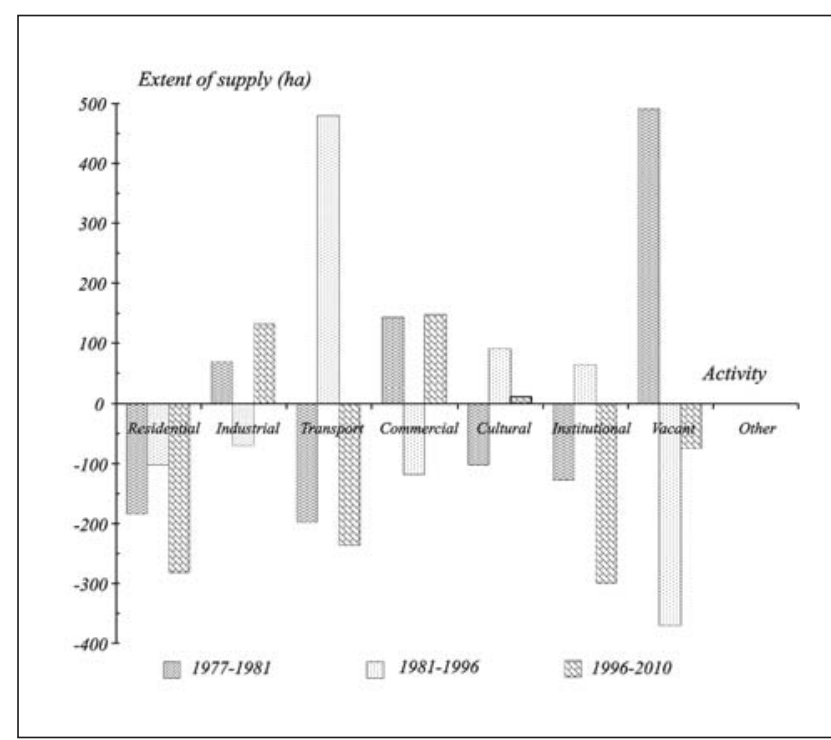

Figure 3: Pattern of net land supply

According to the above-identified trend, a negative supply is apparent in the residential sector for the whole period of time under consideration. This simply means that, even the existing extent of land to cater for the necessities of residential usage is decreasing over the period of time considered. However, the fast increment of this negative figure depicts that the land supply pattern of Colombo city is moving away from residential usage.

Land supplied for the Industrial and commercial sectors exhibit exceptionally similar pattern of movement over time. But the taller columns of commercial sector imply that it carries quicker deviation over time. Both sectors show negative shifts in 1981 as the economic, civil and political unrest prevails in the island. Nevertheless, their overall increments of supply imply that Colombo is promptly industrialising and commercialising throughout the time.

A prompt rise of the land supplied to transport sector is observed in the period 1981-1996. However, a negative figure is observed in the period 1996-2010, which may be due to the selected land supply sources. This could change if land owned by Port and Railway Corporation is also computed and governments' attempts to upgrade the national road transportation facilities in the next five years is to be considered.

The extent of supply of vacant lands during the time period 1977-1981 is noticeably high. However, it is negative thereafter. This implies from 1981 to 2010 the net available extent of vacant lands are decreasing.

To predict the demand trends the study looks at the increasing land prices (see Figure 4) based on data received by the interviewees.

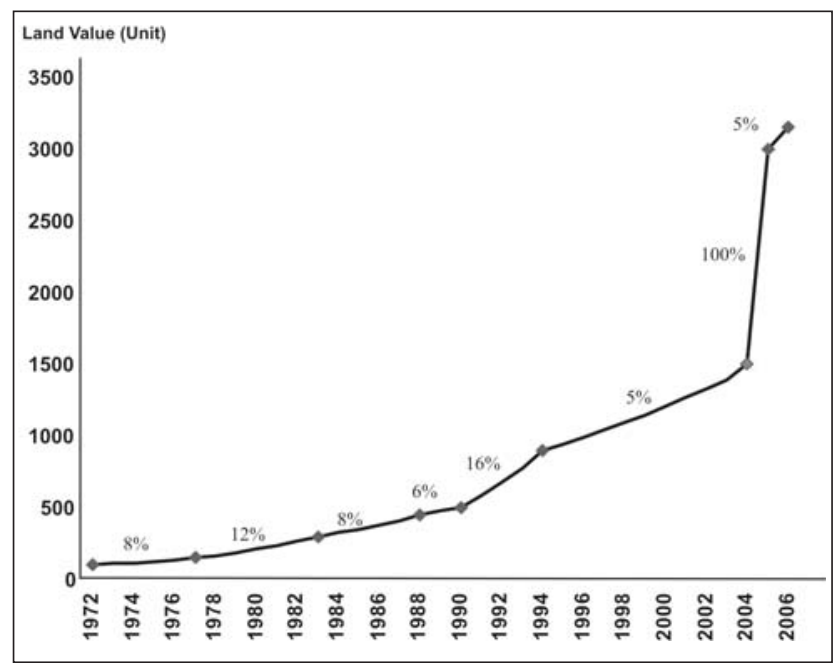

Figure 4: Increasing trend of land values during 1972-2006

Figure 4 represents the trend of increasing land values during the years 1972 through to 2006. The reasons behind this trend are discussed below.

After 1972 most of the private lands were wrested by government with the establishment of Land Reform Law of 1972. There were restrictions on land ownership. When people came to know that lands were wrested by the government they were reluctant to invest on land. Due to this decreased investment by private developers, the demand for land decreased. This led to a lower growth rate during this period.

In 1977, the change of government and a more liberal government economic policy led to rapid increase in economic activities. The removal of some of the restrictive laws pertaining to ceiling prices on house and property and the emergence of liberal economic atmosphere led to a corresponding increase in construction activities culminating in the building boom in mid 1980s. The derived demand for land increased steadily as reflected in higher land prices. During 19771983 land values had a growth rate of $12 \%$ per annum, which was comparatively higher than the rate for the 1972-1977 period.

During the $1983-1988$ and $1988-1990$ periods of political upheavals and civil unrests there was a discouragement of economic activities in the country. People's morale 
was low and the minds were focused mainly on political issues of the day. Riots were common and these caused considerable damages to properties. As a result, the demand for land decreased and a lower growth rate observed ( $8 \%$ and $6 \%$ respectively) when compared to the earlier time period (1977-1983).

In the 1990s, with a new president in place, there were significant development activities in the country. 'Gam Udava' and 'Mahaweli', for example, had established their garment factories in the country. People were encouraged to invest on lands during this time. As a result, the demand for land increased with the growth rate of $16 \%$ - a higher growth rate than the earlier periods.

During the 1994 to 2004 period, development activities were comparatively less when compared to the preceding periods. The growth rate dropped to $5 \%$ during this period. At the end of the year 2004, Sri Lanka faced the Tsunami disaster. In the beginning of the year 2005, foreign funds came into the country mostly through non-government organizations (NGOs') as relief funds for those affected people in the country. This had led to an increase in the demand for land and land prices had doubled during last year. By the end of year 2005, the land prices had stabilized.

A further attempt has been taken to explore current land prices in commercial and residential sectors in the City of Colombo. The price data collected are shown in the Figure 5.

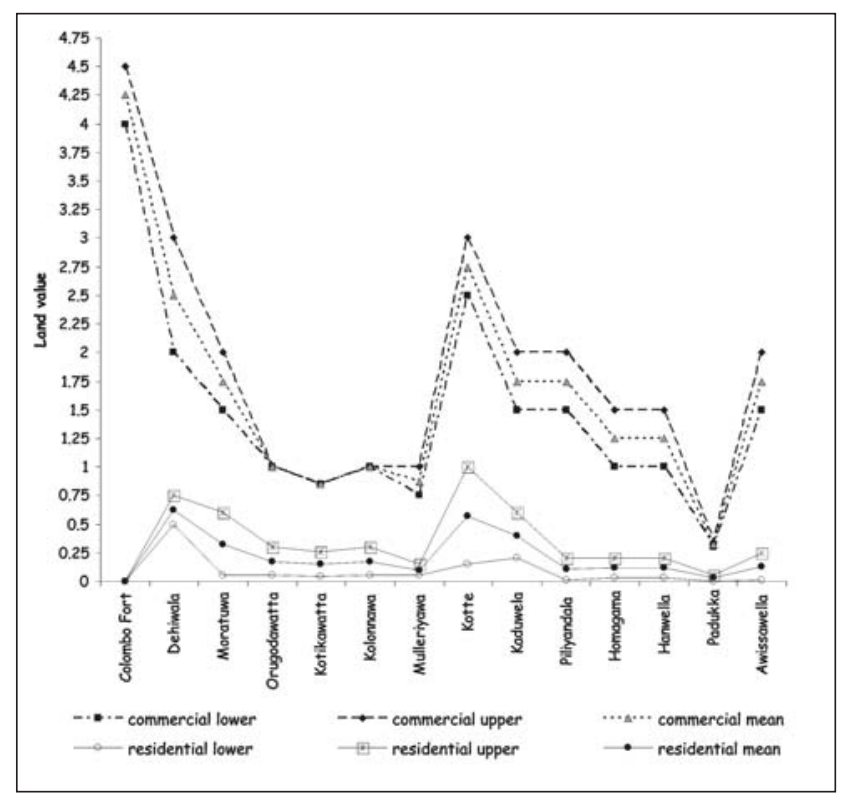

Figure 5: Market Value of Land suitable for development in the Colombo Metropolitan Region (CMR)

According the graph above, commercial land values in the city of Colombo in the period of study are seldom less than Rs. 1 Million per perch. The highest value is recorded in the Colombo Fort locality with the median range of Rs. 2.0 to 3.0 Million per perch recorded in the Dehiwala and Kotte localities. The land values in the Moratuwa, Kaduwela, Piliyandala and Awissawella localities are in 1.5 to 2.0 Million per perch range. Land values for residential purpose are substantially lower with values in the Dehiwala and Kotte localities taking the lead at between Rs. 0.5 to 1.0 Million per perch range.

\section{CONCLUSION}

The research focused on land supply for property development in the Colombo Metropolitan Region (CMR), in terms of factors affecting land supply, sources of land supply and land supply patterns. The aim of the study was to make property developers in the Colombo region knowledgeable on land available for different types of property developments.

This study reveals that around $30 \%$ of the lands are not readily consumable for development projects due to certain physical and legal barriers. Thus, there is a sub-optimal utilization of the available lands located in the CMR. Especially, some high valued lands are occupied by squatters resulting in this sub-optimal use. Even though, the government has a relocation plan, the execution of the plan can take a long period as the government has to relocate these squatters either in temporary housing till permanent dwellings can be erected; or, occupy them directly in permanent housing. Low cost apartments are identified as the most practical solution in this regard.

In terms of land values, there is a notable appreciation of land values in the Colombo Metropolitan Region in the immediate post Tsunami period. The prices quoted for usable parcels of development land in the CMR doubled in this period. There is an artificial demand created by foreigners and aid agencies coming into the country and this does not have a considerable impact on the general public of the country. Currently, land prices are observed as getting stabilized and coming down to reasonable ranges.

Another significant finding of this study is the rapid movement from residential developments to commercial developments in the CMR. This is mainly due to economic liberalization of the country starting from 1977. A substantial increase in commercial and industrial activities and Colombo has been noted as Colombo owns the country's main sea- and air-port. Also, the private sector involvement in property development has increased after this liberal economic policy. All these have led to a high demand for commercial sector land, and thus, the city of Colombo should accommodate this demand while allowing residential sector to rise in the peripherals of the region rather than in the city centre. 


\section{REFERENCES}

BARLOW, J. (1993) "Controlling the housing market: some examples from Europe," Urban Studies, 30: 1129-1149.

DOWALL, D. E. (1993) "The Role and Function of Urban Land Markets in Market Economies." In: Proceedings of the Workshop on Privatization of Land in Ukraine, Ukraine, May 12-14.

EVANS, A.W. (1996) "The impact of land use planning and tax subsidies on the supply and price of housing in Britain: a comment," Urban Studies, 33: $581-585$.

HUI, E. C. (2004) "An empirical study of the effects of land supply and lease conditions on the housing market: A case of Hong Kong," Property Management, 22(2): 127-154.
KIRINGODA, T. (2002) "Should pola in urban centres have permanent buildings?" Journal of Urban Development Authority, 3: 31-32.

PERERA, A.L. S. (1996) "Some Land Planning and Land Development Issues in Sri Lanka," Department of Town and Country Planning, University of Moratuwa, Sri Lanka.

UDA, (1998a) Colombo Metropolitan Regional Structure - Synthesis (Volume1). Ministry of Housing \& Urban Development: UDA.

UDA, (1998b) Colombo Metropolitan Regional StructureCore Area Plan, Planning \& Building Regulations (Volume4). Ministry of Housing \& Urban Development: UDA.

WILTSHAW, D.G. (1985) "The supply of land," Urban Studies, 22: 49-56. 